\author{
R.T. Dinzhumanova, B.Kh. Mussabayeva, R.S. Abekova, N.B. Kassenova \\ Shakarim State University of Semey, Kazakhstan \\ (E-mail: raushan.dinzhuma@mail.ru)
}

\title{
About quantitative determination of flavonoids in vegetative raw materials
}

\begin{abstract}
Numerous researches show that the medicines created on the basis of flavonoids are high performance antineoplastic tools, have antioxidatic properties, reduce risk of diseases of cardiovascular system. Currently physical and chemical methods of the analysis, such as spectrophotometry, absorption spectroscopy are widely used for the identification and quantitative determination of flavonoids in medicines. However, combined methods involving various variants of chromatographic separation of the investigated components are increasingly spreading. Wide use of physicochemical and combined methods of analysis is primarily due to the fact that these methods have a much greater sensitivity and selectivity in comparison with modern chemical and electrochemical methods. Literary data on researching new, and also development and exploitation of existing methods for quantitive determination of flavonoids in vegetative raw were generalized and analyzed. Special attention is paid to such analyzing methods as method of high-performance liquid chromatography, spectrophotometry and chromato-mass-spectrometry. The HPLC method is a fast, highly reproducible method that requires a small amount of analyte and is used for quantitative, qualitative analysis and preparative release. The most accessible and objective method for controlling biologically active compounds in plant raw materials is the chromato-mass-spectrometric method of analysis, which makes it possible to identify individual flavonoids, regardless of the presence of extraneous or related compounds. It is established that most of the studies are based on the methods for the quantitative determination of flavonoids, set out in the European and British pharmacopoeias, and are widely used to standardize many types of raw materials containing flavonoids.
\end{abstract}

Keywords: flavonoids, quercetin, high-performance liquid chromatography, spectrophotometry, complexometric titration.

\section{Introduction}

Currently pharmacologists are interested in substances of flavonoids group. Flavonoids are a group of widespread natural antioxidants in which moleculestwo benzene rings linked by a three carbon fragment containing oxygen. These compounds are a part of many medicines and dietary supplements (DS) and have a number of beneficial properties for the human body. Numerous researches have shown that the medicines created on the basis of these substances are highly effective antineoplastic means, have antioxidant properties, reduce risk of diseases of cardiovascular system [1-8].

It should be noted that valuable feature of flavonoids, along with high biological activity, is their low toxicity.

Depending on the structure of the oxygen-containing fragment flavonoids are classified into several classes (see Fig.). Depending on the number and the nature of substituents on the benzene rings flavonoids subdivide also into subclasses [3,9]. Flavonoids are widespread in flora, particularly in higher plants belonging to the bean, Rosacea, Asteraceae, buckwheat families [3,9].

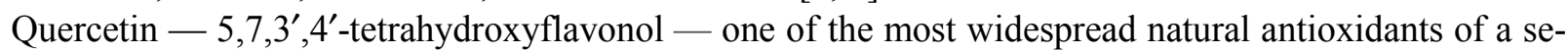
ries of flavonoids which is a part of many medicinal preparations and DS. It possesses a wide range of biological effect on a human body, in particular, anticancerogenic, anti-inflammatory, antioxidatic, antihistamine action, slows down processes of cell aging of a skin, cornea, myocardium [3, 9-12].

\section{Materials and methods}

Along with quercetin the reare relatively large amounts of individual flavonoids in plant facilities. So the task of the selective isolation of their raw materials and their subsequent determination requires the use of different methods of analysis of natural objects, which give the opportunity to fully characterize complex composition and low content of flavonoids.

Currently, physical and chemical methods of analysis, such as spectrophotometry, absorption spectroscopy widely used for identification and quantification of flavonoids in drugs. However, increasingly used the combined methods, including various options for the chromatographic separation of the investigated components. Wide use of the physical and chemical and combined analysis methods, first of all, is bound to the fact 
that these methods have considerably larger sensitivity and selectivity in comparison with the modern chemical and electrochemical methods.

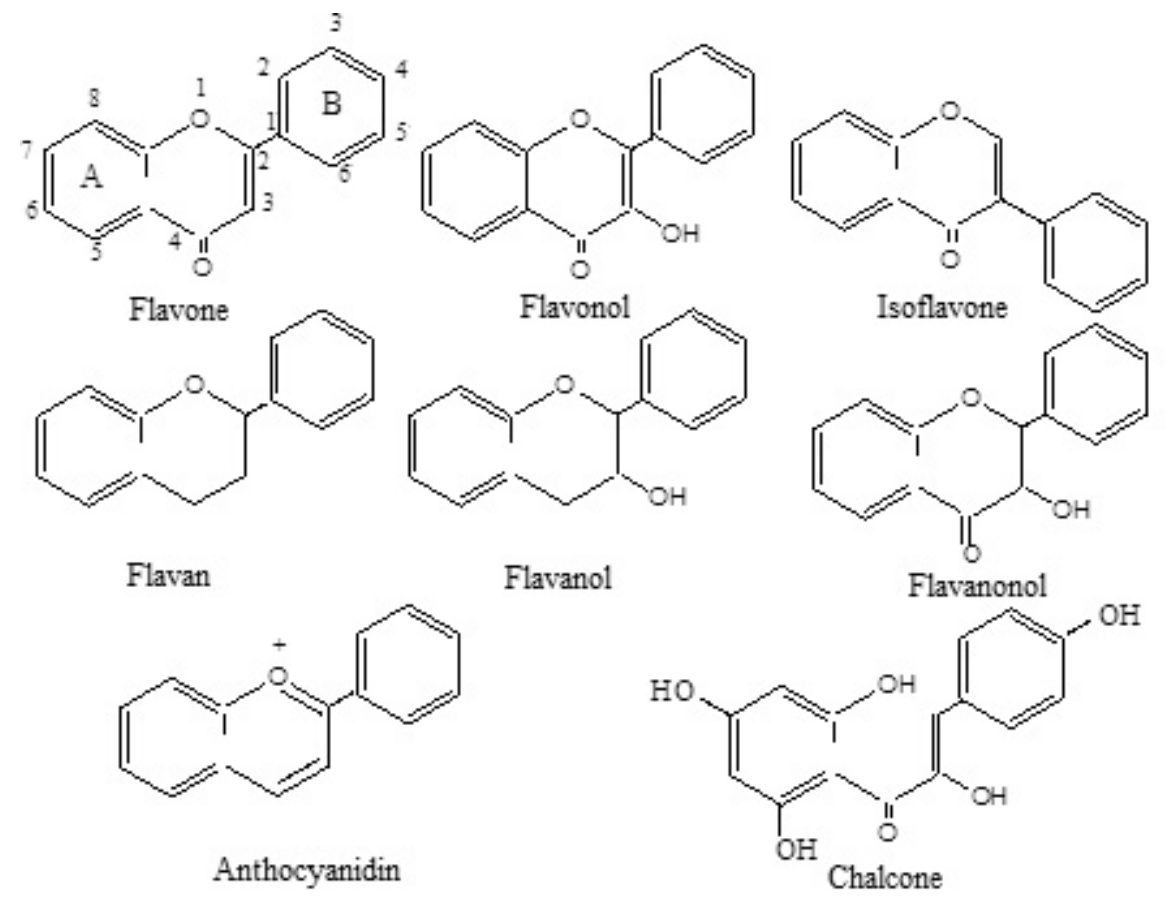

Figure. Members of the main classes of natural flavonoids

The adsorption and chromatographic method is used for division of flavonoids among themselves and separations from the accompanying substances [7].

\section{Results and discussion}

For determination of flavonoids in extracts from plants as well as in foods often use high-performance liquid chromatography (HPLC) after pre-concentration of flavonoids using solid phase extraction. In this case the selection or group identification of flavonoids is complicated by restriction of quantity of sorbents.

The HPLC method is a rapid, highly reproducible method which requires a small amount of an analyte and is used for quantitative and qualitative analysis of preparative selection[13].

For flavonoids columns with versed and phase sorbents and detection with a UV-visible detector with variable wavelength are more used. Currently widely used photodiode detector, which allows to obtain UVvisible spectrum of the substance simultaneously with the release of the peak in the chromatogram. This experimental reception considerably facilitates a problem of identification of substances. Mobile phases (eluent systems) tend to be binary and contain acidic polar component (aqueous solutions of acetic, per chloric acid, phosphoric acid or formic acid) and a less polar organic solvent (acetonitrile or methanol) [13, 14].

Gradient mode is most suitable for the separation of complex mixtures of flavonoids. For columns with reversed-phase sorbents typical gradient programs are based on the use of mobile phases with prevalence at the start of the proportion of polar solvent with a further gradual increase in the proportion of a less polar solvent. Correlation peaks in the chromatogram is the most difficult task. A convenient technique is the use of parallel chromatography of standard samples and compare them with the chromatogram of the investigated object. Standard substance should ideally be more akin flavonoids and have similar chromatographic properties. When standard substance is chromatographed under the same conditions, but in parallel, it is called an external standard. Internal standard (added to the investigated sample before putting into the chromatograph) must meet the following conditions: in the mixture should not contain analogous substance and peakof standard must not overlap with any compound in the mixture. Such restrictions are absent in the case of using an external standard. The advantages of an internal standard is the validation of extraction, sample preparation, chromatographic procedures. Rutinum is often used as a standard substance for flavonoids, it is a commercial available product. It is well suited for quantitative analysis of flavonol glycosides. For other flavonoids which are contained in mixture such commercially available standards as apigenin-7-glucoside - 
for flavone glycosides, catechin - for flavan-3-ols, naringenin - for dihydroflavons, dihydroquercetin for dihydroflavonols, daidzein - for isoflavones can be used [13,14]. For the quantitative analysis the graph of concentration of the flavonoid versus the area of peak for each standard is constructed. The corresponding calibration curves can be used for calculation of quantity of the flavonoid represented by each peak of HPLC chromatogram. Currently, almost disappeared need for the construction of calibration curves due to provision of chromatographs with computer system which is calculated area of peaks [14].

For the quantitative determination of flavonoids using volumetric methods of analysis. So the method of complexometric titration of excess lead acetate, is not entered in the deposition reaction with flavonols, has sufficient selectivity and allows the determination of flavonols in the presence of acetylsalicylic acids, anthraquinones, coumarins. The method of oxidation of flavonoids with potassium ferrocyanide on p-phenyl - aptronilic acid also belongs to a titrimetric method of the analysis. However the method is long and has no selectivity.

Potentiometric titration of the quantitative determination of flavonoids relates to a method of electrochemical analysis, based on the measurement of change during the titration of the electrochemical potential of the electrode immersed in the test solution. Quantitative determination of flavonoids in non-aqueous solvent medium, for example, acetone, dimethylformamide, dimethylsulfoxide by a potentiometric method perhaps with use as titrant of a hydroxide of a tetraethylammonium or sodium. This method gives more accurate results, and does not require standard substances for quantifying compared with optical methods. Low sensitivity (required for analysis $0.0005-0.001 \mathrm{~g}$ of substance) and poor selectivity for each of the classes difficult to identify without prior separation of substances in raw materials and total preparations [15].

Reduction of flavonoids on a mercury dropping electrode is the basis for a highly sensitive polarographic method of the analysis. The method allows to analyze the amount of flavonoids, in terms of one of connections chosen as the standard. The method gives results more close to the true cooperative contents for flavonoids unlike a spectophotometery of the colored complexes Flavonoids (flavanols) can be defined against the background of $0.4 \mathrm{M}$ ammonium chloride solution at a half-wave potential of $1.5 \mathrm{~V}$. Polarographic method allows the presence of intramolecular bonds, the identification largest half-wave potential, evaluate the reactivity of the individual groups in the molecule. In practice of the pharmaceutical analysis and in particular industrially the polarographic analysis has difficulties as demands keeping of rigorous conditions of the accident prevention during the work with Hydrargyrum. The disadvantages of the method are its low selectivity because of the close values of half-waves of potentials, in connection with what is required, as in the case of spectral methods, preliminary separation of substances [16].

In modern science, for the detection and quantification of flavonoids in the plant material is also used capillary electrophoresis method [17]. The method of a capillary electrophoresis is based on division of components of the complex mixture in a quartz capillary under the influence of the enclosed electric field. The microvolume of the analyzed solution is entered into the capillary beforehand filled with the suitable buffer - electrolyte. After supplying a high voltage to the ends of the capillary $(30 \mathrm{kV})$, the components of the mixture begins to move through the capillary at different rates, depending primarily on charge and mass (or rather - ionic radius) and, respectively, at different times reach the detection zone. The resulting sequence of peaks called electrophoregrams. Qualitative characteristic of the substance is the retention parameter (during migration), and quantitative - height or peak area, which is proportional to the concentration of the substance. The advantages of capillary electrophoresis are: high separation efficiency, economy (low consumption of reagents) and expressivity.

Quantitative determination of the investigated flavonoid compound in the UV- and visible spectra based on measurement of an optical density at a wavelength in maxima of absorption both solutions of the analyzed substances, and solutions of their painted complexes. Spectrophotometric determination of the maxima of the intrinsic absorption is one of the most common methods for the analysis of flavonoids. At the same time serve as working ranges of lengths of waves as long-wave maxima for flavonoids - 330-370 nm, and shortwave. Shortwave maxima, although more intense, but in many cases less suitable for analytical purposes due to the small «area» top peak, which leads to large errors in the determination. The relative error of the direct spectrophotometric determination is $\pm 2-5 \%$ and can be reduced in the differential analysis technique to $0.5-1.0 \%$. The working range of concentrations of alcohol, water-alcohol solutions is from 5 to $20 \mathrm{~g}$ substance in $1 \mathrm{ml}$. With its high sensitivity, the method is not selective because they do not control the content of each of the substances of the class of compounds [18].

Spectrophotometric or photometric determination by diazotization reaction were previously widely distributed in the analysis. The reaction is sensitive, but not selective, because along with flavonoids phenolic 
connections, pyrazyl ketones and other classes of connections give this reaction. Even total determination with this reactant do not show the true content of the studied substances, both in cooperative phytochemical medicines, and in vegetable raw materials.

Techniques of determination of flavanols on color complex compounds with aluminum chloride, zirconium oxychloride (zirconyl chloride), gallium nitrate have larger specificity. The colored solutions have maxima in intervals: $385-460 \mathrm{~nm}$ with aluminum chloride, $385-500 \mathrm{~nm}$ with zirconyl chloride, $400-455 \mathrm{~nm}$ with gallium nitrate. Method using gallium nitrate, allowing quantification of $0.5 \mu \mathrm{g}$ in $1 \mathrm{~mL}$ of the solution, then zirconium oxychloride - $0.9-1.0 \mu \mathrm{g}$ and aluminum chloride $-1-2 \mu \mathrm{g}$ has the greatest sensitivity $[19,20]$.

Methods of the analysis of flavonoids with cobalt nitrite in the medium of an acetic acid at a wavelength of $575 \mathrm{~nm}$, and also with zinc and arsenic are described. It is possible to receive the true cooperative maintenance of flavonoids by training of color complexes with metals only in the presence at connections of identical quantity of the complexing centers. Despite these drawbacks, a method has been widely used in determining total flavonoid content in raw materials and total phytochemical preparations. As a standard used quercetin, kaempferol and their glycosides [9].

A photometric method for determining the complexation reaction with boric acid at a wavelength of $470 \mathrm{~nm}$ is widely used in determining the total amount of flavonoid compounds in plants. The technique has the same disadvantages as the method of complexation with metal salts, and gives higher results but the simplicity and availability of reagent allowed to use them for indicative determinations. As samples are used aglycones, glycosides of flavones, flavonols, chalcones. Working concentration of solutions $1-10 \mu \mathrm{g} / \mathrm{ml}$. The relative error of determination is $\pm 3.35 \%$.

Borohydride method is most sensitive in the range of spectrophotometric methods for the analysis of flavanones (up to $0.5-1 \mu \mathrm{g} / \mathrm{mL}$ at wavelengths of $535-560 \mathrm{~nm}$ ). Despite considerable selectivity, it is not widely used because of the short time stability of the colored complex and poor reproducibility of results.

Fluorometric method is based on the complexone-forming properties of flavonoids, which is more sensitive than spectrophotometric. It is possible to determine flavonoids quantitatively by this method, if in $1 \mathrm{ml}$ of solution - $0.05-1 \mu \mathrm{g}$ of substance. The high sensitivity of fluorometric method allows us to use it for the preliminary identification of biologically active substances in plant tissues. However, to obtain the correct results in the analysis of raw materials and phytochemical preparations is possible only after separation of substances by using various kinds of chromatography.

Chromato-mass spectrometers - method for analysis of mixtures, mainly organic substances and determination of trace amounts of substances in the volume of liquid. The method is based on a combination of the two independent methods - chromatography and mass spectrometry. With the first method, is performed on the separation of the mixture, using a second - identification and determination of structure of the substance, quantitative analysis. There are two options of chromato-mass spectrometers: a combination of mass spectrometry with a gas-liquid chromatography (GC) or HPLC.

The paper contains idea of quantification of flavonoids in elderberry extract, enriched in phenolic acids, polyphenolic flavonoids and other compounds through the use of mass spectrometry DART (Direct Analysis in Real Time), which differs from the conventional mass spectrometry in that the ionization of low molecules from the surface of the liquid or solid objects in the gas allows to do without stages of sample preparation and chromatographic separation [21].

\section{Conclusions}

Flavonoids are extremely multifaceted. Equally, they are interesting as objects of study in Botany, Pharmacognosy, Phytochemistry, and especially in pharmacy and medicine.

In this paper flavonoids mainly studied from chemical positions. Namely, the basic methods of quantitative determination of flavonoids in herbal drugs are considered. Particular attention is paid to such methods of analysis as a method of high performance liquid chromatography, spectrophotometry and gas chromatography-mass spectrometry. The basis of most of the research is the method of quantitative determination of flavonoids as set out in the European and British Pharmacopoeia, and is widely used for the standardization of many raw materials containing flavonoids [22, 23]. It was established that the most reasonable and objective method for monitoring of biologically active compounds in plant material and summary of phytochemical preparations is chromato-mass-spectrometric analysis method that allows the identification of individual flavonoids is not dependent on the presence of extraneous or related compounds. 


\section{References}

1 Arredondo M.F. Cytoprotection by Achyroclinesatureioides (Lam) D.C. and some of its main flavonoids against oxidate stress / M.F. Arredondo, F. Blasina, C. Echeverry, A. Morguio, M. Ferreira, J.A. Abin-Carriguiry, et al. // Ethnopharmacology. 2004. - Vol. 91, No. 1. - P. 13-20.

2 Tsao R. Separation procedures for naturally occurring antioxidant phylochemicals / R. Tsao, Z. Deng. // Chromatogr. B. 2004. - Vol. 812, No. 1-2. - P. 85-99.

3 Andersen O.M. Flavonoids: chemistry, biochemistry and applications / O.M. Andersen, K.R. Markham. — Boca Raton: Taylor \& Francis Group. LLC, 2006.

4 Blasa M. Honey flavonoids as protection agents against oxidative damage to human red blood cells / M. Blasa, M. Candiracci, A. Accorsi, M.P. Piacentini, E. Piatti // Food Chem. — 2007. — Vol. 104, No. 4. — P. 1635-1640.

5 Soobrattee M.A. Phenolies as potential antioxidant therapeutic agents: mechanism and actions / M.A. Soobrattee, V.S. Neergheen, A. Luximon-Ramma, O.I. Aruoma, T. Bahorun // Mutation Res. - 2005. — Vol. 579, No. 1-2. — P. $200-213$.

6 Ninfali P. Characterization and biological activity of the main flavonoids from Swiss Chard (Beta vulgaris subspecies cycla) / Ninfali P., Bacchiocca M., Antonelli A., Biagiotti E., Di Gioacchino A.M., Piccoli G., et al. // Phytomedicine. — 2007. — Vol. 14, No. 2-3. - P. 216-221.

7 Ferreira R. de Q. Electrochemical determination of the relative capacity: the Ceric Reducing/Antioxidant Capacity (CRAC) assay / R. de Q. Ferreira, L.A. Avaca // Electroanalyses. - 2008. - Vol. 20, No. 12. - P. 1323-1329.

8 Zielinka D. Determination of the relative contribution of quercetin and its glucosides to the antioxidant capacity of onion by cyclic voltammetry and spectrophotometric methods / D. Zielinka, W. Wiezkowski, M.K. Piskula // Agric. Food Chem. - 2008. Vol. 58, No. 10. - P. 3524-3531.

9 Корулькин Д.Ю. Природные флавоноиды / Д.Ю. Корулькин, Ж.А. Абилов, Р.А. Музычкина, Г.А. Толстиков. - Новосибирск: Гео, 2007.

10 Tan W. Quercetin, a dietary-derived flavonoid, possesses antiangiogenic potential / W. Tan, M. Li, Y. Zhang, Y. Tong, D. Xiao, J. Ding // Eur. J. Pharm. - 2003. - Vol. 459, No. 2-3. - P. 255-262.

11 Беликов В.Г. Фармацевтическая химия: в 2 ч. - Ч. 2. Специальная фармацевтическая химия / В.Г. Беликов. - Пятигорск, 2003.

12 Bozin B. Phenolics as antioxidants in garlic (Allium sativum L., Alliaceae) / B. Bozin, N. Mimica-Dukic, I. Samojlik, A. Goran, R. Igic // Food Chem. - 2008. - Vol. 111, No. 4. - P. 925-929.

13 Тюкавкина Н.А. Органическая химия: учебник для вузов: в 2 кн. - Кн. 2: Специальный курс / Н.А. Тюкавкина, С.Э. Зурабян, В.Л. Белобородов. - М.: Дрофа, 2008.

14 Сычев С.Н. Высокоэффективная жидкостная хроматография на микроколоночных хроматографах серии «Милихром»: моногр. / С.Н. Сычев, К.С. Сычев, В.А. Гаврилина. — Орел: ОГТУ, 2002.

15 Васильев В.П. Аналитическая химия. Физико-химические методы анализа: учеб. для студ. вузов, обучающихся по химико-технол. спец. / В.П. Васильев. - 2-е изд., перераб. и доп. - М.: Дрофа, 2002.

16 Лебедева М.И. Аналитическая химия и физико-химические методы анализа / М.И. Лебедева. — Тамбов: ТГТУ, 2005.

17 Абдуллабекова В.Н. Идентификация рутина в растительном сырье методом капиллярного электрофореза / В.Н. Абдуллабекова // Вестник фармации. — 2009 - № 3. - С. 23-28.

18 Золотов Ю.А. Основы аналитической химии: в 2 кн. - Кн. 2. Методы химического анализа / Ю.А. Золотов, Е.Н. Дорохова, В.И. Фадеева. - М.: Высш. шк., 2002.

19 Ильясова С.М. Выявление флавоноидов в листьях калины / С.М. Ильясова и Д.М. Попов // Фармация. — 2005. T. 5. - C. $12-15$.

20 Ожигова М.Г. Количественное определение суммарного содержания флавоноидов в листьях Urticadioica (Upticaceae) спектрофотометрическим методом / М.Г. Ожигова, М.В. Богма, Л.С. Теслов // Растительные ресурсы. — 2006. - Т. 42 , № 2. - C. $126-130$.

21 Чернецова Е.C. Масс-спектрометрия DART и ее применение в химическом анализе / Е.С. Чернецова, Г.Е. Морлок, Ч.А. Ревельский // Успехи химии. - 2011. - Т. 80, № 3. - С. 249-271.

22 British Pharmacopoeia 2009. - BHMA, Bournemouth: Crown Publishers, 2008.

23 European Pharmacopoeia 6th Edition // Council of Europe European-European Directorate for the Quality of Medicines. 2007.

\section{Р.Т. Дінжұманова, Б.Х. Мұсабаева, Р.С. Абекова, Н.Б. Қасенова}

\section{Өсімдік шикізаттағы флавоноидтерді сандық анықтау әдістері туралы}

Көптеген зерттеулер бойынша флавоноидтерге негізделген препараттар жоғары деңгейде ісікке қарсы құралдар болып табылады, тотығуға қарсы қасиеттері бар және жүрек қан-тамыр жүйесінің ауруларының қауіпін азайтады. Флавоноидтердің құнды ерекшелігі — олардың уыттылығы төмен. Қазіргі кезде дәрілік құралдардағы флавоноидтерді анықтау үшін спектрофотометрия, абсорбциялық спектроскопия сияқты, физика-химиялық талдау әдістері кеңінен қолданылады. Зерттелетін компоненттерді хроматографиялық бөлудің әр түрлі варианттарын қамтамасыз ететін құрама әдістер де кеңінен пайдалануда. Қазіргі кездегі химиялық және электрохимиялық әдістермен салыстырғанда, физика-химиялық және комбинирленген талдау әдістерінің кеңінен қолданылуы олардың неғұрлым 
үлкен сезімталдығына және іріктілігіне байланысты. Жұмыста өсімдік шикізаттағы флавоноидтерді саңдық анықтаудың жаңа әдістері және казіргі кезде қолданылатын әдістерді дамыту жөніндегі әдеби мәліметтер талданды және сарапталды. Жоғары нәтижелі сұйықтық хроматография, спектрофотометрия және хроматомасспектрометрия сияқты әдістерге ерекше назар бөлінді. Жоғары нәтижелі сұйықтық хроматография - өте тез және жақсы өндірілетін, зерттелетін заттың аз мөлшерін қажет ететін, сапалық және сандық талдауда, заттарды препараттық бөліп алуда қолданылатын әдіс. Өсімдік шикізаттағы биологиялық белсенді заттарды бақылаудың ең тиімді және нақты әдісі хроматомасспектрометрия. Бұл әдіс бөгде және флавоноидтерге ұқсас қосылыстардың болуына тәуелсіз жеке флавоноидтарды идентификациялауға мүмкіндік береді. Көптеген зерттеулердің Еуропалық және Британ фармакопеясында көрсетілген флавоноидтардың сандық анықталу әдістеріне негізделгені анықталды.

Кілт сөздер: флавоноидтар, кверцетин, жоғары сапалы сұйық хроматография, спектрофотометрия, комплексометриялық титрлеу.

\title{
Р.Т. Динжуманова, Б.Х. Мусабаева, Р.С. Абекова, Н.Б. Касенова О методах количественного определения флавоноидов в растительном сырье
}

\begin{abstract}
Многочисленные исследования показывают, что препараты, созданные на основе флавоноидов, являются высокоэффективными противоопухолевыми средствами, обладают антиоксидантными свойствами, снижают риск заболеваний сердечно-сосудистой системы. В настоящее время для идентификации и количественного определения флавоноидов в лекарственных средствах широко используются физико-химические методы анализа, такие как спектрофотометрия, абсорбционная спектроскопия. Однако все большее распространение получают комбинированные методы, включающие различные варианты хроматографического разделения исследуемых компонентов. Широкое использование физико-химических и комбинированных методов анализа, в первую очередь, связано с тем, что эти методы обладают значительно большей чувствительностью и селективностью по сравнению с современными химическими и электрохимическими методами. В работе обобщены и проанализированы литературные данные по разработке новых, а также развитию и применению существующих методов количественного определения флавоноидов в растительном сырье. Особое внимание уделено таким методам анализа, как метод высокоэффективной жидкостной хроматографии (ВЭЖХ), спектрофотометрия и хроматомасспектрометрия. Метод ВЭЖХ является быстрым, хорошо воспроизводимым методом, который требует малого количества анализируемого вещества и используется для количественного, качественного анализа и препаративного выделения. Наиболее доступным и объективным методом контроля биологически активных соединений в растительном сырье является хроматомасспектрометрический метод анализа, позволяющий идентифицировать отдельные флавоноиды независимо от присутствия посторонних или родственных соединений. Установлено, что большинство исследований основаны на методиках количественного определения флавоноидов, изложенных в Европейской и Британской фармакопеях и широко применяемых для стандартизации многих видов сырья, содержащих флавоноиды.
\end{abstract}

Ключевые слова: флавоноиды, кверцетин, высокоэффективная жидкостная хроматография, спектрофотометрия, комплексометрическое титрование.

\section{References}

1 Arredondo, M.F., Blasina, F., Echeverry, C., Morguio, A., Ferreira, M., \& Abin-Carriguiry, J.A. et al. (2004). Cytoprotection by Achyroclinesatureioides (Lam) D.C. and some of its main flavonoids against oxidate stress. Ethnopharmacology, 91, 1, 13-20.

2 Tsao, R., \& Deng, Z. (2004). Separation procedures for naturally occurring antioxidant phylochemicals. Chromatogr. B., 812, $1-2,85-99$.

3 Andersen, O.M., \& Markham, K.R. (2006). Flavonoids: chemistry, biochemistry and applications. Boca Raton: Taylor \& Francis Group. LLC.

4 Blasa, M., Candiracci, M., Accorsi, A., Piacentini, M.P. \& Piatti, E. (2007). Honey flavonoids as protection agents against oxidative damage to human red blood cells. Food Chem., 104, 4, 1635-1640.

5 Soobrattee, M.A., Neergheen, V.S., Luximon-Ramma, A., Aruoma, O.I., \& Bahorun, T. (2005). Phenolies as potential antioxidant therapeutic agents: Mechanism and actions. Mutation Res., 579, 1-2, $200-213$.

6 Ninfali, P., Bacchiocca, M., Antonelli, A., Biagiotti, E., Di Gioacchino, A.M., \& Piccoli, G. et al. (2007). Characterization and biological activity of the main flavonoids from Swiss Chard (Beta vulgaris subspecies cycla). Phytomedicine, 14, 2-3, $216-221$.

7 Ferreira, R. de Q., \& Avaca, L.A. (2008). Electrochemical determination of the relative capacity: the Ceric Reducing/Antioxidant Capacity (CRAC) assay. Electroanalyses, 20, 12, 1323-1329. 
8 Zielinka, D., Wiezkowski, W., \& Piskula, M.K. (2008). Determination of the relative contribution of quercetin and its glucosides to the antioxidant capacity of onion by cyclic voltammetry and spetrophotometric methods. Agric. Food Chem., 58, 10, $3524-3531$.

9 Korulkin, D.Yu., Abilov, Zh.A., Muzychkina, R.A., \& Tolstikov, G.A. (2007). Prirodnye flavonoidy [Natural flavonoids]. Novosibirsk: Geo [in Russian].

10 Tan, W., Li, M., Zhang, Y., Tong, Y., Xiao, D., \& Ding, J. (2003). Quercetin, a dietary-derived flavonoid, possesses antiangiogenic potential. Eur. J. Pharm, 459, 2-3, 255-262.

11 Belikov, V.G. (2003). Farmatsevticheskaia khimiia: $v 2$ ch. Ch.2 Spetsialnaia farmatsevticheskaia khimiia [Pharmaceutical chemistry: in 2 parts. Part 2. Special pharmaceutical chemistry]. Pyatigorsk [in Russian].

12 Bozin, B., Mimica-Dukic, N., Samojlik, I., Goran, A., \& Igic, R. (2008). Phenolics as antioxidants in garlic (Allium sativum L., Alliaceae). Food Chem., 111, 4, 925-929.

13 Tiukavkina, N.A., Zurabyian, S.E., \& Beloborodov, V.L. (2008). Orhanicheskaia khimiia: v 2 kn. Kn.2: Spetsialnyi kurs [Organic chemistry: in 2 books. Book 2: Special course]. Moscow: Drofa [in Russian].

14 Sychev, S.N., Sychev, K.S., \& Havrilina, V.A. (2002). Vysokoeffektivnaia zhidkostnaia khromatohrafiia na mikrokolonochnykh khromatohrafakh serii «Milikhrom» [High-performance liquid chromatography on microcolumn chromatographs of the Milichrom series]. Orel: OGTU [in Russian].

15 Vasilev, V.P. (2002). Analiticheskaia khimiia. Fiziko-khimicheskie metody analiza [Analytical chemistry. Physicochemical methods of analysis]. (2nd ed.). Moscow: Drofa [in Russian].

16 Lebedeva, M.I. (2005). Analiticheskaia khimiia i fiziko-khimicheskie metody analiza [Analytical chemistry and physicochemical methods of analysis]. Tambov: TGTU [in Russian].

17 Abdullabekova, V. Kh. (2009). Identifikatciia rutina v rastitelnom syre metodom kappiliarnoho elektroforeza [Identification of rutin in plant raw materials by the method of capillary electrophoresis]. Vestnik farmatcii. - Bulletin of Pharmacy, 3, 23-28 [in Russian].

18 Zolotov, Yu. A., Dorokhova, E.N., \& Fadeeva, V.I. (2002). Osnovy analiticheskoi khimii. v 2 kn. Kn. 2. Metody khimicheskoho analiza [Fundamentals of analytical chemistry. In 2 books. Book 2. Methods of chemical analysis]. Moscow: Vysshaia shkola [in Russian].

19 Iliasova, S.M., \& Popov D.M. (2005). Vyiavlenie flavonoidov v listiakh kaliny [Detection of flavonoids in leaves of the viburnum]. Farmatsiia - Pharmacy, 5, 12-15 [in Russian].

20 Ozhigova, M.G., Bogma, M.V., \& Teslov, L.S. (2006). Kolichestvennoe opredelenie summarnoho soderzhaniia flavonoidov $\mathrm{v}$ listyah Urticadioica (Upticaceae) spektrofotometricheskim metodom [Quantitative determination of the total content of flavonoids in leaves of Urticadioica (Upticaceae) by spectrophotometric method]. Rastitelnye resursy. - Vegetable resources, 42, 2, $126-130$. [in Russian].

21 Chernetsova, E.S., Morlok, G.E., \& Revelskii, Ch.A. (2011). Mass-spektrometriia DART i ee primenenie v khimicheskom analize [DART mass spectrometry and its application in chemical analysis]. Uspekhi khimii. - Advances in Chemistry, 80(3), 249271 [in Russian].

22 British Pharmacopoeia 2009. (2008). BHMA, Bournemouth: Crown Publishers.

23 European Pharmacopoeia 6th Edition. (2007). Council of Europe European — European Directorate for the Quality of Medicines. 